\title{
THE INFLUENCE OF SELECTED PROCESS PARAMETERS ON THE REACTIONS OF $n$-HEXANE ISOMERIZATION AND TRANSESTERIFICATION CATALYZED BY SULFATED ZIRCONIA
}

\author{
Nikola Stojković, Marija Vasić, Radomir Ljupković, Aleksandra Zarubica*
}

(ORIGINAL SCIENTIFIC PAPER) UDC 66.095.21.097:546.831:544.4

Faculty of Science and Mathematics, University of Niš, Niš, Serbia

In view of the recent (ever) increasing need for environmentally friendly fuels, the processes of $n$-alkane isomerization and triglyceride(s) transesterification have gained importance because they enable the reduction of emissions of various hazardous substances into the environment. In this paper, sulfated $\mathrm{ZrO}_{2}$ as a heterogeneous acid catalyst was used in model reactions of isomerization of $n$-hexane and transesterification of sunflower oil. The goal of this research was to determine the optimal process parameters for isomerization and transesterification reactions, since they can have a large influence on both ecological and economical validity of these processes when used on the industrial scale. For the transesterification process, the parameters investigated were: the catalyst loading and methanol to oil molar ratio whereas in the isomerization reaction, the optimal process temperature was determined. The catalyst loading was proven to increase the yield of transesterification, but only until the mass percentage of the catalyst reaches $10 \%$. The optimum methanol to oil molar ratio was shown to be 60:1, as further increase of the methanol amount decreases the transesterification yield. The temperature of $325^{\circ} \mathrm{C}$ was determined to be optimal for the reaction of $n$-hexane isomerization under the experimental conditions applied.
Keywords: Isomerization, process parameters, sulfated zirconia, transesterification

\section{Introduction}

In recent years, gasoline manufacturers have been required to impose new and more restrictive standards, especially concerning the contents of olefins and aromatic compounds in gasoline. This fact limits the use of reforming and catalytic cracking in refineries and has a goal of improving the ecological situation on the planet [1]. As a consequence, the reaction of $n$-alkane isomerization has gained importance, since it is a safe and ecologically favorable way to increase the octane number of gasoline by yielding di- and trimethyl isomers of normal alkanes which replace the hazardous high octane number compounds the contents of which have now been limited [2].

Another way of lowering the negative influence of fossil fuel burning on the atmosphere is the use of biofuels which has been rising worldwide, especially since 2012 [3]. Biodiesel is currently the most convenient type of biofuel in car industry, because of the fact that it does not require any modification of the existing diesel powered vehicles [4]. It is industrially produced by transesterification of oils and/ or fats [5].

Because of its favorable textural, structural, morphological and surface properties, sulfated zirconia was proven to be an efficient heterogeneous catalyst for many industrial processes, including isomerization of $n$-hexane and transesterification of triglycerides (i.e. biodiesel production) [6]. While sulfated zirconia is often used with different promotors, its activity in $n$-hexane isomerization reaction and a desired product yield has already been determined and shown to depend mainly on the catalyst surface properties [7]. Transesterification reactions can be very different depending on the catalyst used and the variations in reaction conditions. An excess of methanol has been reported to have a negative effect on the biodiesel yield, and a wide range of methanol to oil molar ratios (from 6:1 up to 84:1) has been reported as optimal [8].

However, in addition to depending on the catalyst type (physico-chemical properties) and a reactor design (potential diffusion restrictions), the reactions of $n$-alkane isomerization and triglyceride transesterification depend heavily on reaction parameters such as: temperature, catalyst loading, rate of stirring, pressure, etc. In this paper, sulfated zirconia was used in reactions of $n$-hexane isomerization and sunflower oil transesterification. Selected parameters of reactions were tested in the attempt to find an optimal value of each parameter.

\section{Experimental}

\section{Catalyst synthesis}

Catalyst samples were synthesized using zirconium-oxynitrate $\left(\mathrm{ZrO}\left(\mathrm{NO}_{3}\right)_{2} \cdot \mathrm{xH}_{2} \mathrm{O}\right)$ as a precursor. The precipitation of zirconium-hydroxide was carried out from the zirconium-

\footnotetext{
* Author address: Aleksandra Zarubica, Faculty of Science and Mathematics, University of Niš,

Višegradska 33, 18000 Niš, Serbia

E-mail: zarubica2000@yahoo.com

The manuscript received: March, 24, 2017

Paper accepted: May, 09, 2017.
} 
oxynitrate aqueous solution by slowly adding $\mathrm{NH}_{4} \mathrm{OH}(25 \%)$ during $2 \mathrm{~h}$ until $\mathrm{pH} 9$ was reached. After that, the precipitate was filtered, rinsed with distilled water until there was no trace of nitrates left in the filtrate. Afterwards, the precipitate was dried, and subsequently sulfated and calcined. The sulfation procedure was performed by wet-impregnation with $\mathrm{H}_{2} \mathrm{SO}_{4}(0.5 \mathrm{M})$ under vacuum. The amount/volume of the acid solution was calculated for concrete catalyst samples to have nominal mass of $4 \%$ of sulfates. Calcination was performed at $500{ }^{\circ} \mathrm{C}$ for $3 \mathrm{~h}$ in the synthetic air flow of $25 \mathrm{~cm}^{3} / \mathrm{min}$. Catalysts were then used in test reactions of $n$-hexane isomerization and transesterification of sunflower oil.

\section{Materials}

Sunflower oil (brand "Sunce", Dijamant Co.) was obtained from a local market. The free fatty acid(s) content was found to be below the detection limit and the water content was found to be below 0.3 mass \%. The fatty acid(s) content of sunflower oil was determined by using GC/MS and presented in Table 1. Methanol (HPLC grade) and the catalyst precursor $\left(\mathrm{ZrO}\left(\mathrm{NO}_{3}\right)_{2} \cdot \mathrm{xH}_{2} \mathrm{O}\right)$ were obtained from Sigma-Aldrich.

Table 1. Fatty acid composition of sunflower oil.

\begin{tabular}{lll}
\hline Fatty acid & Formula & $\%$ by weight \\
\hline Palmitic & $\mathrm{C}_{16} \mathrm{H}_{32} \mathrm{O}_{2}$ & 9.21 \\
Stearic & $\mathrm{C}_{18} \mathrm{H}_{36} \mathrm{O}_{2}$ & 6.45 \\
Oleic & $\mathrm{C}_{18} \mathrm{H}_{34} \mathrm{O}_{2}$ & 19.32 \\
Linoleic & $\mathrm{C}_{18} \mathrm{H}_{32} \mathrm{O}_{2}$ & 61.2 \\
Eicosenoic & $\mathrm{C}_{20} \mathrm{H}_{38} \mathrm{O}_{2}$ & 1.1 \\
Behenic & $\mathrm{C}_{22} \mathrm{H}_{44} \mathrm{O}_{2}$ & 1.73 \\
Lingoceric & $\mathrm{C}_{24} \mathrm{H}_{48} \mathrm{O}_{2}$ & 0.63 \\
\hline
\end{tabular}

\section{Test reactions}

Isomerization of $n$-hexane was performed under the atmospheric pressure and constant partial pressure of $n$-hexane of 62 mbar. Helium was used as a carrier gas, and its molar ratio to $n$-hexane was set at 16.5. Catalyst samples were inserted into the quartz microreactor and activated in situ in the synthetic air flow of $25 \mathrm{~cm}^{3} / \mathrm{min}$ for $2 \mathrm{~h}$ under the temperature of $450^{\circ} \mathrm{C}$. After the activation period, after 10 minutes of the reaction, the initial activity was recorded. The reaction temperature was chosen as a varying parameter. The catalysts were tested at reaction temperatures of $225^{\circ} \mathrm{C}$ and $325^{\circ} \mathrm{C}$. Reaction products were separated on PONA GC-capillary column and then analyzed by gas chromatography (GC-HP 5890) with FID detection. The conversion of $n$-hexane was determined in relation to each of the derived gas-phase products and normalized by the number of $\mathrm{C}$-atoms for the reactant and product(s). The selectivity for the formation of an individual product was calculated by dividing the normalized conversion of $n$-hexane of the particular product with the total $n$-hexane conversion.

Transesterification reactions were performed in a round bottom flask (batch conditions) with a reflux condenser and using a magnetic stirrer. The stirring speed was set at $400 \mathrm{rpm}$, under the atmospheric pressure at the temperature of boiling of the mixture $\left(65^{\circ} \mathrm{C}\right.$, reflux $)$ and the reaction time was $72 \mathrm{~h}$. Catalysts samples were dried at $100{ }^{\circ} \mathrm{C}$ for $3 \mathrm{~h}$ before the reaction, and then added to the prepared mixture of oil and methanol. Transesterification process parameters were varied in the appropriate manner:

- Mass percentages (mass \%) of the catalyst (in relation to the total mass of the reaction mixture) used for the intended tests were: 1, 2, 3, 5, 10 and 15\%;

- Methanol to oil molar ratios were set as follows: $20: 1$, $30: 1,60: 1,90: 1$ and 120:1.

Following the transesterification reaction, the product mixture underwent consecutive evaporation and extraction procedures in order to eliminate methanol. Afterwards, the ${ }^{1} \mathrm{H}$ NMR analysis was performed according to Knothe [9], in order to determine the yield of FAME. The ${ }^{1} \mathrm{H}$ NMR spectra of the reaction mixture samples were recorded at $25^{\circ} \mathrm{C}$ on a Bruker Avance III $400 \mathrm{MHz}$ NMR spectrometer $\left({ }^{1} \mathrm{H}\right.$ at $400 \mathrm{MHz},{ }^{13} \mathrm{C}$ at $\left.100 \mathrm{MHz}\right)$ using $\mathrm{CDCl}_{3}$ as the solvent. Chemical shifts were expressed as $\delta(\mathrm{ppm})$ using tetramethylsilane as the internal standard. 2D experiments $\left({ }^{1} \mathrm{H}-{ }^{1} \mathrm{H}\right.$ COSY, NOESY, TOCSY, HSQC and $\mathrm{HMBC}$ ), as well as DEPT-90 and DEPT-135, were run on the same instrument with usual pulse sequences. The example of the obtained NMR spectrum of the biodiesel product mixture is presented in Fig. 1.

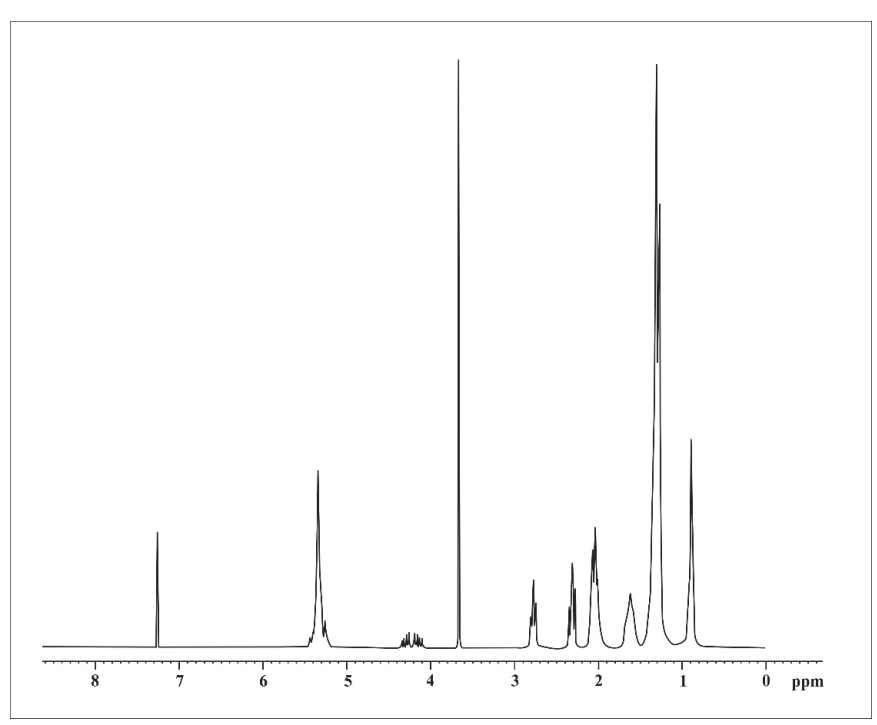

Figure 1. NMR of the biodiesel product mixture

The yield of biodiesel was calculated according to Knothe [9]:

$$
C_{K}=100 \times\left(\frac{5 \times I_{M E}}{5 \times I_{M E}+9 \times I_{A G}}\right)
$$

Where: IME is the integration value of the methyl ester peak (3.70) and $I_{A G}$ is the integration value of glyceridic peaks $(4.10-4.40)$.

The GC/MS analyses were carried out using a Hewlett-Packard 6890N gas chromatograph equipped with a fused silica capillary column, DB-5MS (5\% phenylmethylsiloxane, $30 \mathrm{~m} \times 0.25 \mathrm{~mm}$, film thickness $0.25 \mu \mathrm{m}$, 
Agilent Technologies, USA) and coupled with a 5975B mass selective detector from the same company.

The injector and interface were operated at: $250{ }^{\circ} \mathrm{C}$ and $300{ }^{\circ} \mathrm{C}$, respectively.

\section{Results and discussion}

Reaction of isomerization of $n$-hexane

Influence of the reaction temperature

Reaction temperature influences both the conversion of $n$-hexane in the reaction of isomerization and the selectivity of the reaction to favorable $\left(i-\mathrm{C}_{6}\right)$ products. The results of our investigations of the optimal reaction temperature are shown in Figure 2. Increasing the reaction temperature from $225^{\circ} \mathrm{C}$ to $325^{\circ} \mathrm{C}$ had a somewhat positive influence on the reaction selectivity to $i-\mathrm{C}_{6}$, and the reaction conversion. The higher catalyst efficiency and reaction yield (conversion) is easily explained by the increased possibility of effective collisions, since kinetic energy of the reactant and catalyst particles are increased at higher temperatures.

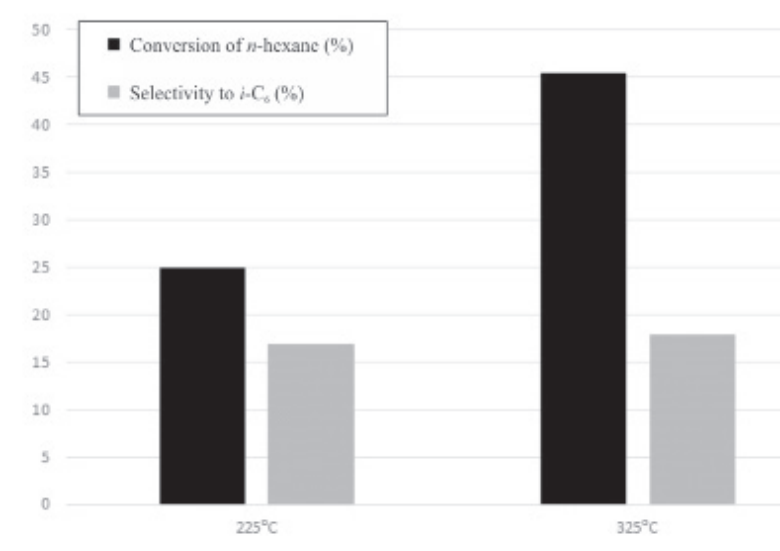

Figure 2. Influence of the reaction temperature on $n$-hexane conversion and $i-\mathrm{C}_{6}$ selectivity

These results are somewhat different from previously reported $[10,11]$ since, in most cases the increase of temperature seemed to have a negative influence on the selectivity while increasing the reaction conversion. In our paper, the selectivity also increased with the increase of the reaction temperature, but only slightly. It was found that a number of catalyst properties have an influence on conversion and selectivity in $n$-alkane isomerization reactions, especially due to the complexity of the process [12-14]. Namely, favorable surface properties (especially the presence and number of Bronsted acid sites together with Lewis acid sites), along with a high specific surface area, a dominant tetragonal crystal phase, and a suitable type of porosity (mesoporous system) have a major influence on the catalyst activity. A high number of acid sites on the catalyst surface increase the possibility of its interaction with the reactants, and favorable pore diameter and volume will allow the reactants to enter the inner area of the catalyst, therefore increasing the sur- face available for the reaction which in turn increases the catalyst activity.

\section{Transesterification reaction \\ Catalyst amount}

Catalyst loading (in this paper presented as catalyst mass \%) is an important parameter in transesterification reactions. A higher catalyst amount means a higher number of catalytically active sites, which in turn should lead to the higher catalyst activity/total efficiency. On the other hand, the use of a high catalyst amount is not always economical, since the catalyst is relatively expensive and its high content in the reaction mixture often leads to additional difficulties in the product (fatty acid methyl ester - FAME and glycerol) separation, which are in some cases viewed as financially inefficient. A number of authors have assessed the possibility of use of sulfated zirconia in more than one reaction cycle and have reported that the catalyst can be regenerated by different processes [15-18], but all those require time and degrade the catalyst quality.

Figure 3 displays the results of our research in discovering the optimal catalyst amount for the transesterification reaction. The increase of the catalyst mass \% leads to the higher reaction yield, which is easily explained by the increased catalyst surface and thus the increased number of catalytically active sites (Fig. 3). Furthermore, the increase from 10 to $15 \%$ mass does not continue to significantly increase the FAME yield. Considering the complexity of the process, namely the three-step reaction and its acid-catalyzed mechanism, it is possible that further increase of the catalyst loading (above 10\%) no longer increases the number of effective collisions. The reason for this might be found in variation of other factors such as the methanol content and/or stirring speed. However, further investigation in this regard is required. Other studies have reported a wide range from 1 to $10 \%$ mass of the catalyst as optimal $[19,20]$.

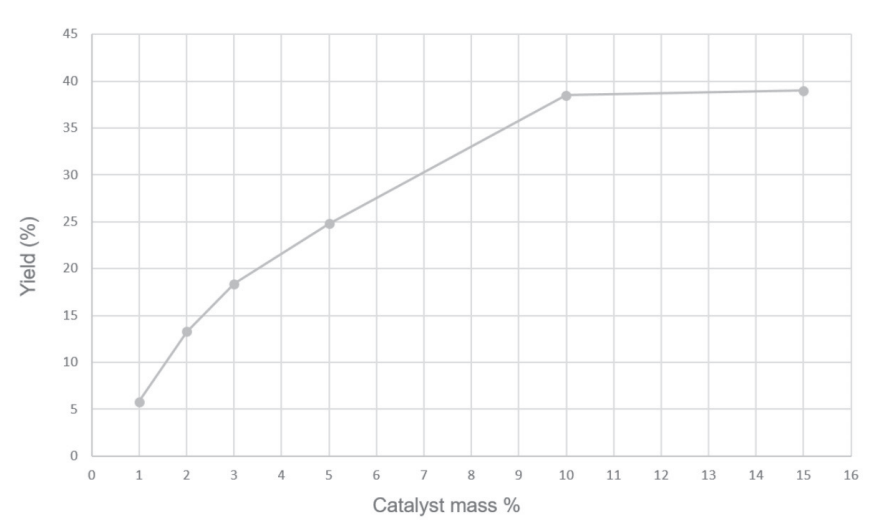

Figure 3. Influence of the catalyst mass $\%$ on the biodiesel yield

Methanol to oil molar ratio

Transesterification of triglycerides is a reaction that involves methanol and triglycerides in a stoichiometric 
molar ratio of $3: 1$. Since the reaction is reversible, the equilibrium position depends on the concentration of reactants and products in the solution (reactor system).

Naturally, the industrial process requires the highest possible yield of products, which means that the equilibrium needs to be moved to the right side. According to Le Chatelier principle, this can be achieved by increasing the concentration of reactants. In this case, it means the increase of methanol to triglyceride (oil) molar ratio more than 3:1 [21].

In addition, it was reported that an excess of methanol is useful because it removes FAMEs and glycerol from the catalyst surface, thus regenerating it and improving its efficiency. Standard homogeneous and heterogeneous base catalysis in the Esterfip- $\mathrm{H}$ reactor often uses the ratios of $6: 1$ and 9:1 [22-25]. The mechanism of transesterification catalyzed by acids is such that the reaction is estimated to be around 4000 times slower than the same reaction when catalyzed by bases [26], thus higher molar ratios of methanol to oil/fat $60: 1$ are often used [27-29].

Depending on the oil used, the reactor construction and a number of other parameters, the product mixture can be complex and comprised of many phases. Significant resources are expended in order to extract FAME as a primary product, as well as glycerol and an excess of methanol, which are important issues of the product from an economic perspective. In these conditions, the use of a large amount of methanol is unfavorable, and the methanol to oil molar ratio should not be higher than needed for obtaining high enough yields [30].

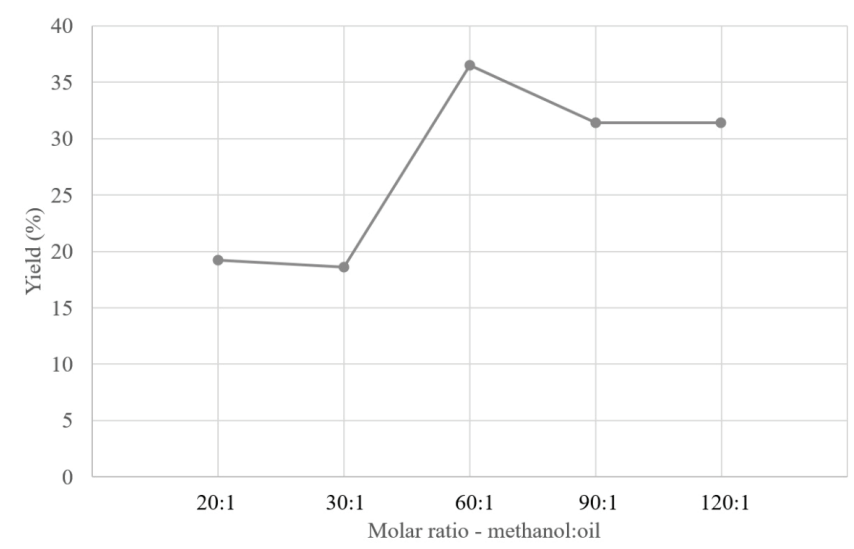

Figure 4. Influence of methanol to oil molar ratio on the biodiesel yield

Figure 4. shows the influence of methanol to oil molar ratio on the yield of FAME. The amount of the catalyst was set at $10 \%$ mass in relation to the reaction mixture, as this was determined as optimal in previous considerations within this paper. As it can be clearly seen from Fig. 4 , the increase of methanol to oil molar ratio increases the FAME yield, but only until the molar ratio of $60: 1$ has been reached. Further increase in the methanol amount decreases the FAME yield (Fig. 4). Similar results were obtained in a number of papers under (relatively) different conditions and using a similar acid catalyst [31-33]. As a possible explanation for the decrease of the process yield with the overly high methanol amount, the authors theorize that, despite favorable catalyst properties (primarily a large number of Bronsted acid sites) [27,34], the high amount of methanol may decrease the possibility of triglyceride molecules accessing the catalyst surface. This points out the importance of the efficient phase contact in heterogeneous catalysis as an essential parameter influencing the yield. However, further investigations are required in this regard.

\section{Conclusion}

The sulfated zirconia catalyst analyzed in this paper has demonstrated the activity in both the reaction of $n$ hexane isomerization and sunflower oil transesterification.

The temperature of $325{ }^{\circ} \mathrm{C}$ was determined to be a favorable temperature for isomerization in terms of the significant increase of conversion. On the other hand, selectivity has only slightly increased with the increase of the reaction temperature.

It was determined that the catalyst loading increase has a positive effect on the FAME yield in the transesterification reaction performed. However, this is only the case when increasing the catalyst loading up to $10 \%$ mass, since further catalyst amount increase ceases to have a positive effect on the reaction yield.

The increase of the methanol amount increases the reaction yield, but only until methanol to oil molar ratio reaches $60: 1$, after which a further increase of methanol has a (significant) negative effect on the reaction yield.

\section{Acknowledgement}

The authors wish to thank the Ministry of Education, Science and Technological Development of the Republic of Serbia (Projects Ol 1612008, Ol 172061, TR 34008) for a financial support.

\section{References}

[1] G. Valavarasu, B. Sairam, Light Naphtha Isomerization Process: A Review, Petroleum Science and Technology, 31 (2013) $580-595$.

[2] O. V. Dzhikiya, M. D. Smolikov, E. V. Zatolokina, K. V. Kazantsev, A. S. Belyi, Isomerization of $n$-hexane on $\mathrm{Pd} / \mathrm{SO}_{4}{ }^{2} / \mathrm{ZrO}_{2} / \mathrm{Al}_{2} \mathrm{O}_{3}$ and mechanical mixtures $\mathrm{Pd} / \mathrm{Al}_{2} \mathrm{O}_{3}$ $\left(\mathrm{Pd} / \mathrm{SiO}_{2}\right)+\mathrm{SO}_{4}^{2-} / \mathrm{ZrO}_{2} / \mathrm{Al}_{2} \mathrm{O}_{3}$, Procedia Engineering, 152 (2016) $116-121$.

[3] M. Crocker, R. Andrews, Thermochemical Conversion of Biomass to Liquid Fuels and Chemicals, Center for Applied Energy Research, University of Kentucky, Lexington, USA, 2010.

[4] G. Knothe, J. Van Gerpen and J. Krahl, The Biodiesel Handbook, AOCS Press, Champaign, Illinois, USA 2005.

[5] M. Balat and M. F. Demirbas, Bio-oil from pyrolysis of 
black alder wood, Energy Sources Part A, 31, (2009) 1719 - 1727.

[6] B. M. Reddy, M. K. Patil, Organic Syntheses and Transformations Catalyzed by Sulfated Zirconia, Chemical Reviews, 109(6) (2009) 2185 - 2208.

[7] G.G. Volkova, S. I. Reshetnikov, L.N. Shkuratova, E. A. Paukshtis, $n$-Hexane skeletal isomerization over sulfated zirconia catalysts with different Lewis acidity, The Chemical Engineering Journal, 134 (2007) 106 - 110.

[8] Y.C. Sharma, B. Singh, S.N. Upadhyay, Advancements in development and characterization of biodiesel: A review, Fuel, 87 (2008) 2355-2373.

[9] G. Knothe, Monitoring a progressing transesterification reaction by fiber-optic near infrared spectroscopy with correlation to $1 \mathrm{H}$ nuclear magnetic resonance spectroscopy, Journal of The American Oil Chemists Society, 77 (2000) $489-493$.

[10] F. Lonyi, A. Kovacs, J. Valyon, Hexane Isomerization and Cracking Activity and Intrinsic Acidity of H-Zeolites and Sulfated Zirconia-Titania, The Journal of Physical Chemistry B, 110 (2006) 1711 - 1721.

[11] L. Bikmetova, M. Smolikov, E. Zatolokina, K. Kazantsev, V. Tregubenko, A. Belyi, Supported sulfated zirconia catalysts for isomerization of $n$-hexane, Procedia Engineering 152 (2016) 87 - 93.

[12] A. Zarubica, B. Jovic, P. Nikolic, P. Putanov and G. Boskovic, Temperature imposed textural and surface synergism affecting isomerization activity of sulfated zirconia catalyst, Journal of Serbian Chemical Society, 74 (2009) 14 - 29.

[13] PA. Jacobs, J. A. Martens, E. M. van Bekkum, J.C. Jansen, Introduction to Acid Catalysis with Zeolites in Hydrocarbon Reactions, Elsevier, Amsterdam, The Netherlands, 1991, $445-496$.

[14] X. Li, K. Nagaoka, L.J. Simon, R Olindo, J.A. Lercher, Influence of calcination procedure on the catalytic property of sulfated zirconia, Cataysis. Letters 113, (2007).

[15] J. Kansedo and K. Teong Lee, Transesterification of palm oil and crude sea mango (Cerbera odollam) oil: The active role of simplified sulfated zirconia catalyst, Biomass and Bioenergy, 40 (2012) 96-104.

[16] K. Suwannakarn, E. Lotero, J. G. Goodwin Jr. and C. Lu, Stability of sulfated zirconia and the nature of the catalytically active species in the transesterification of triglycerides, Journal of Catalysis., 255 (2008) 279-286.

[17] D. E. Lopez, J. G. Goodwin, D. A. Bruce, S. Furuta, Esterification and transesterification using modifiedzirconia catalysts, Applied Catalysis A:General, 339 (15) (2008) 76-83.

[18] C. M. Garcia, S. Teixeira, L. L. Marciniuk, U. Schuchardt, Transesterification of soybean oil catalyzed by sulfated zirconia, Bioresourourse Technologies, 99 (2008) 66086613.

[19] Juan A. Melero, L. Fernando Bautista, G. Morales, J. Iglesias, and D. Briones, Biodiesel Production with Heterogeneous Sulfonic Acid-Functionalized Mesostructured Catalysts, Energy \& Fuels, 23 (2009) 539-547.

[20] D. Rattanaphra, A. P. Harvey, A. Thanapimmetha, P. Srinophakun, Simultaneous transesterification and esterification for biodiesel production with and without a sulphated zirconia catalyst, Fuel, 97 (2012) 467 - 475.

[21] M. G. Kulkarni, R. Gopinath, L. C. Meher, A. K. Dalai, Solid acid catalyzed biodiesel production by simultaneous esterification and transesterification. Green Chemistry, 8 (2006) 1056-1062.

[22] A. Chouhan, A. Sarma, Modern heterogeneous catalysts for biodiesel production: A comprehensive review, Renewable and Sustainable Energy Reviews, 15(9) (2011) 4378-4399.

[23] L. C. Meher, S. N. Naik and L. Das, Methanolysis of Pongamia pinnata (karanja) oil for production of biodiesel, Journal of Scientific and Industrial Research, 63 (2004) 913-918.

[24] H. Raheman and A. G. Phadatare, Diesel engine emissions and performance from blends of karanja methyl ester and diesel, Biomass and Bioenergy, 27 (2004) 393-397.

[25] S. K. Peters, R. Ganswindt, H. P. Neuner and E. Weinder, Alcoholysis of triacylglycerols by heterogeneous catalysis, European Journal of Lipid Science and Technology, 104(3) (2002) 324-330.

[26] A. Demirbas, Biodiesel: A Realistic Fuel Alternative for Diesel Engines, Springer-Verlag London Limited, London, United Kingdom, 2008.

[27] J. Kaita, T. Mimura, N. Fukuoda, Y. Hattori, Catalysts for transesterification. U.S. Pat. 6407269, (2002).

[28] E. Lotero, Y. Liu, D. E. Lopez, K. Suwannakarn, D. A Bruce, J. G. Goodwin Jr., Synthesis of Biodiesel via Acid Catalysis, Industrial and Engineering Chemistry Research, 44 (2005) 5353 - 5363.

[29] N. Stojkovic, M. Vasic, R. Ljupkovic, M. Marinkovic, M. Randjelovic, A. Zarubica, Influence of catalyst properties on biodiesel production from sunflower oil via sulfated zirconia: Total acidity and sulfur in highest oxidation state - essential factors for catalytic efficiency, Oxidation communications 40 (1) (2017).

[30] R. E. Horne, N.D. Morimer, M. A. Elsayed, Energy and Carbon Balances of Biofuels Production: Biodiesel and Ethanol, Proceedings No. 510, International Fertiliser Society (2003).

[31] Q. Shu, J. Gao, Z. Nawaz, Y. Liao, D. Wang, J. Wang, Synthesis of biodiesel from waste vegetable oil with large amounts of free fatty acids using a carbon based solid acid catalyst. Applied Energy, 87 (2010) 2589 - 2596.

[32] Y.S. Li, S. Lian, D.M. Tong, R.L. Song, W.Y. Yang, Y. Fan, R.W. Qing, C.W. Hu, One-step production of biodiesel from Nannochloropsis sp. on solid base $\mathrm{Mg}-\mathrm{Zr}$ catalyst. Applied Energy 88 (2011) 3313 - 3317.

[33] G. Teng, L. Gao, G. Xiao, H. Liu, Transesterification of soybean oil to biodiesel over heterogeneous solid base catalyst. Energy and Fuels, 23 (2009) 4630 - 4634.

[34] N. Stojkovic, M. Vasic, M. Marinkovic, M. Randjelovic, M. Purenovic, P. Putanov and A. Zarubica, A comparative study of $n$-hexane isomerization over solid acid catalysts: sulfated and fosfated zirconia, Chemical Industry and Chemical Engineering Quarterly, 18(2) (2012) 209 - 220. 
Izvod

\section{UTICAJ ODABRANIH PARAMETARA PROCESA NA REAKCIJE IZOMERIZACIJE $n$-HEKSANA I TRANSESTERIFIKACIJE KATALIZOVANE SULFONOVANIM CIRKONIJUM(IV)-OKSIDOM}

Nikola Stojković, Marija Vasić, Radomir Ljupković, Aleksandra Zarubica

Prirodno-matematički fakultet u Nišu, Univerzitet u Nišu, Niš, Srbija

Zbog novih i sve strožih propisa, povećava se potreba za ekološki povoljnim gorivima. U ovakvoj situaciji, procesi izomerizacije $n$-alkana i transesterifikacije triglicerida dobijaju na značaju, zato što omogućavaju umanjenje emisija različitih štetnih materija u životnu sredinu. U ovom radu, $\mathrm{ZrO}_{2}$ modifikovan sulfatima je korišćen kao heterogeni kiseli katalizator za modelne reakcije izomerizacije $n$-heksana i transesterifikacije suncokretovog ulja. Cilj ovog istraživanja je bio određivanje optimalnih parametara procesa izomerizaciije i transesterifikacije, imajući u vidu da oni mogu imati velikog uticaja na ekološku i ekonomsku validnost ovih procesa na industrijskom nivou. Za proces transesterifikacije, parametri koji su uzeti u obzir su: maseni udeo katalizatora i molarni odnos metanola prema ulju, dok je u procesu izomerizacije razmatrana optimalna temperatura reakcije. Uvećavanje količine katalizatora je povećavalo prinos u reakciji transesterifikacije, ali samo do dostizanja masenog udela katalizatora od $10 \%$. Optimalni molarni odnos metanola prema ulju je bio 60:1, a dalje povećanje količine/zapremine metanola je dovelo do smanjenja prinosa reakcije. Temperatura od $325^{\circ} \mathrm{C}$ se pokazala optimalnom reakcionom temperaturom procesa izomerizacije $n$-heksana.
(ORIGINALNI NAUČNI RAD) UDK 66.095.21.097:546.831:544.4

Ključne reči: Izomerizacija, parametri procesa, sulfatima modifikovan $\mathrm{ZrO}_{2}$, transesterifikacija 